\title{
EXPEDIENTE/EDITORIAL TEAM
}

\section{EDITOR GERAL/EDITOR}

Clovis R. Montenegro de Lima

http://lattes.cnpq.br/4727891485011869

\section{EDITORES ASSISTENTES/ ASSISTENT EDITOR}

Ariane Durce Maciel

http://lattes.cnpq.br/9327499050501358

Claudia Bucceroni Guerra

http://lattes.cnpq.br/3337477406324757

Fátima Santana da Silva

http://lattes.cnpq.br/4344959980286555

Geni Chaves Fernandes

http://lattes.cnpq.br/0028214455599057

Kátia de Oliveira Simões

http://lattes.cnpq.br/7032235441412473

Mariângela Rebelo Maia

http://lattes.cnpq.br/5136545258607957

\section{EDITORAÇÃO ELETRÔNICA/ELETRONIC EDITORIAL \\ Daniela Capri \\ http://lattes.cnpq.br/085759182845463}

\section{CAPA/COVER PAINT}

Daniela Capri

http://lattes.cnpq.br/085759182845463 